\title{
НАДАННЯ КОРИСНОЇ ІНФОРМАЦІЇ ПРО МУЗЕЙНІ ПРЕДМЕТИ У ФІНАНСОВІЙ ЗВІТНОСТІ СУБ'ЄКТА ДЕРЖАВНОГО СЕКТОРУ
}

\author{
Ольга Герасименко \\ ПРЕДОСТАВЛЕНИЕ ПОЛЕЗНОЙ ИНФОРМАЦИИ О МУЗЕЙНЫХ \\ ПРЕДМЕТАХ В ФИНАНСОВОЙ ОТЧЕТНОСТИ СУБЪЕКТА \\ ГОСУДАРСТВЕННОГО СЕКТОРА
}

Olha Herasymenko

\section{PROVIDING USEFUL INFORMATION ABOUT MUSEUM ARTICLES IN FINANCIAL STATEMENT OF THE PUBLIC SECTOR ENTITY}

У статті сформовано підходи до вибору, розміщення та організації інформаиії про музейні предмети для ії відображення чи розкриття у фінансовій звітності. Здійснено оиінку корисності иієї інформачії та запропоновано авторський підхід до визнання музейних предметів. Встановлено необхідність доповнення ф. № 1-дс «Баланс» через введення до розділу «Нефінансові активи» статті «Активи спадчини», ф. № 5-дс «Примітки до річної фінансової звітності» через включення додаткового розділу «Активи спадщини», а також пояснень до фінансової звітності. Надання інформаиії про наявність, рух, стан музейних предметів та політику управління ними сприятиме підвищенню якісних характеристик фінансової звітності суб' єкта державного сектору.

Ключові слова: представлення фінансової звітності; корисність інформачїі; визнання музейних предметів; інформація для відображення; інформачія для розкриття; суттєвість та об 'єднання.

Табл.: 2. Бібл.: 22.

В статье сформированы подходы к выбору, размещению и организации информации о музейных предметах для ее отображения или раскрытия в финансовой отчетности. Осуществлена оценка полезности этой информации и предложен авторский подход к признанию музейных предметов. Установлена необходимость дополнения ф. № 1 -гс «Баланс» посредством введения в раздел «Нефинансовые активы» статьи «Активы наследия», ф. № 5-гс «Примечания к годовой финансовой отчетности» посредством включения дополнительного раздела "Активы наследия", а также пояснений к финансовой отчетности. Предоставление информации о наличии, движении, состоянии музейных предметов и политику управления ими будет способствовать повышению качественных характеристик финансовой отчетности субъекта государственного сектора.

Ключевые слова: представление финансовой отчетности, полезность информации, признание музейных предметов, информачия для отображения, информация для раскрытия, существенность и агрегирование

Табл.: 2. Библ.: 22.

Within the article, approaches to the selection, placement and organization of information about museum objects in order to display or disclose it in the financial statements are formed. Usefulness of this information is evaluated and the author's approach to the recognition of museum objects is grounded. The necessity to amend F. No. 1-ds "Balance" by means of introducing it to Section "Non-Financial Assets" of the Article "Heritage Assets", F.No.5-ds "Notes to the Annual Financial Statements" through the introduction of an additional section "Heritage Assets", as well as clarifications to financial statements is established. Providing information on the availability, movement, status of museum objects and management policies will help improve the quality of the financial statements of a public sector entity.

Keywords: presentation of financial statements; information usefulness; recognition of museum objects; display information; disclosure information; materiality and merge.

Table: 2. References: 22.

JEL classification: M41

Постановка проблеми. Ключовою метою фінансової звітності суб' єктів державного сектору є надання користувачам корисної інформації з метою підзвітності та прийняття рішень. Проте найбільш авторитетними органами, відповідальними за розробку стандартів обліку, не сформовано єдиного підходу до представлення інформації про музейні предмети у фінансовій звітності суб'єкта державного сектору. Так, організацією економічного співробітництва та розвитку (англ. Organisation for Economic Co-operation and Development, OECD), яка об'єднує 35 найбільш економічно розвинених країн світу, проаналізовано практику відображення країнами-членами ОЕСР об'єктів спадщини в річних фінансових звітах. Це дослідження виявило, що у зв'язку з відсутністю загальноприйнятих облікових підходів та труднощами з оцінкою активів спадщини, суб'єкти державного сектору лише 43 \% країн визнають активи спадщини (в тому числі музейні предмети) [3]. При цьому, навіть якщо активи спадщини визнані в балансі, то застосовуються різні методи оцінки, що обмежує порівнянність показників звітності.

(C) Герасименко О. М., 2019 
ФІНАНСОВІ РЕСУРСИ: ПРОБЛЕМИ ФОРМУВАННЯ ТА ВИКОРИСТАННЯ

Для вирішення зазначеної проблеми Рада 3 Міжнародних стандартів бухгалтерського обліку в державному секторі (далі - IPSASB) протягом декількох останніх років активно розвиває проєкт «Спадщина» [8], до участі в якому приєднались країни з досвідом бухгалтерського обліку музейних предметів та надання інформації про них у фінансовій звітності. Певною відправною точкою роботи над проєктом стало виокремлення такої облікової категорії, як «активи спадщини» для об'єднання різноманітних елементів спадщини (зокрема й музейних предметів).

В Україні, на відміну від провідного закордонного досвіду, загальнодержавну облікову політику щодо активів спадщини не сформовано, а музейні предмети здебільшого не розглядаються як об'єкти бухгалтерського обліку та елементи фінансової звітності, що потребує грунтовних наукових досліджень. Такі дослідження особливо актуальні в період модернізації бухгалтерського обліку в державному секторі, яка $\epsilon$ необхідною умовою реформування управління державними фінансами та передусім спрямована на адаптацію національної нормативно-правової бази з питань бухгалтерського обліку до міжнародних стандартів, а також на створення надійного інформаційного забезпечення для прийняття рішень.

Аналіз останніх досліджень і публікацій. Перехід на національні стандарти бухгалтерського обліку суб'єктами державного сектору спричинив низку суттєвих змін у формуванні облікової інформації, іiі відображенні та розкритті у фінансовій звітності, що стало предметом дослідження в працях провідних вітчизняних науковців, проте цілісні наукові дослідження стосовно надання інформації про музейні предмети у фінансовій звітності не проводились. Водночас ці питання грунтовно опрацьовані закордонними науковцями, серед яких N. Aversano, J. Antonio, P. Barker, A. Barton, L. Biondi, J. Christiaens, G. Fisher, L. Hay, P. Hone, A. Lacerra, J. Lee, J. Mack, N. Noaman, H. Ouda, A. Stafford та ін. У своїх працях дослідники обгрунтовують необхідність представлення у фінансовій звітності інформації про активи спадщини шляхом формування власного бачення на визнання активів спадщини та розкриття інформації про них.

Виділення недосліджених частин загальної проблеми. Попри напрацювання закордонних дослідників, питання надання інформації про музейні предмети у фінансовій звітності вітчизняних суб'єктів державного сектору залишаються мало дослідженими та набувають дедалі більшої актуальності в умовах переходу до ведення обліку за методом нарахування.

Мета статті. Метою статті $є$ формування пропозицій до вибору, розміщення і організації інформації про музейні предмети для іiї відображення чи розкриття у фінансовій звітності суб'єкта державного сектору.

Виклад основного матеріалу. Вітчизняний стандарт, який визначає склад, форми, принципи підготовки фінансової звітності в державному секторі, загальні вимоги до визнання і розкриття іiі елементів називається НП(С)БОДС 101 «Подання фінансової звітності» [1]. Таким чином, термін «подання фінансової звітності» має досить широке смислове навантаження, яке стосується всіх етапів формування та використання звітності. Проте в НП(С)БОДС 101 та інших нормативно-правових актах із бухгалтерського обліку його сутність не розкрито, а використання звужується до означення дій по передачі уже складеної звітності користувачам у встановлені терміни. Фактично можна стверджувати про спотворення змісту поняття «подання фінансової звітності». Уявляється, що більш вдалим у широкому розумінні цього значення $є$ використання замість поняття «подання фінансової звітності» терміна «представлення фінансової звітності», що узгоджується 3 Міжнародними стандартами бухгалтерського обліку для державного сектору (далі МСБОДС) та Концептуальними основами фінансової звітності загального призначення організацій суспільного сектору (далі - Концептуальні основи) [22]. У цих міжнародних актах у вказаному контексті використовуються терміни «presentation of financial 
ФІНАНСОВІ РЕСУРСИ: ПРОБЛЕМИ ФОРМУВАННЯ ТА ВИКОРИСТАННЯ

statements» [13] або «presentation in general purpose financial reports» [22] (англ. «presentation» - презентація, представлення, подання, виклад і т. ін.). Крім того, у національних стандартах вживаються і такі терміни, як «надання інформації» та «розкриття», а також наведено зв'язок між ними, а саме: «розкриття - надання інформації, яка є суттєвою для користувачів фінансової звітності» [1]. Використання цієї термінології теж не узгоджується з МСБОДС та Концептуальними основами, унаслідок чого «наведена у фінансовій звітності та примітках до неї інформація, може бути неправильно витлумачена користувачем і він не зможе прийняти досить обгрунтовані рішення» [2].

Варто зазначити, що значення термінів, які стосуються представлення фінансової звітності, а також основоположні концепції відображення в ній певних елементів найбільш чітко конкретизують саме Концептуальні основи [22], на змісті яких грунтується це дослідження.

Зокрема, представлення - це вибір, розміщення і організація інформації, яка офіційно надається у фінансовій звітності [22]. Представлення пов'язане з метою фінансової звітності, потребами користувачів, якісними характеристиками та обмеженнями на інформацію, визначенням елементів, критеріями й особливостями визнання, методами оцінки.

Отже, надання інформації про музейні предмети у фінансовій звітності передбачає послідовне проходження трьох етапів, які тісно пов'язані між собою: 1) вибір інформаиіï; 2) розміщення інформаиії; 3) організація інформації.

Вибір інформації, яку слід надавати у фінансовій звітності стосовно музейних предметів, повинен грунтуватись на потребах користувачів та корисності цієї інформації. При цьому ознакою корисності інформації є іiї відповідність таким якісним характеристикам, як доречність, зрозумілість, достовірність, порівнянність, можливість перевірки, своєчасність [22]. Під час оцінювання корисності інформації треба враховувати обмеження на інформацію, до яких належать: суттєвість, співвідношення вигід і витрат; збалансованість якісних характеристик [22].

При формуванні авторського бачення стосовно корисності інформації про музейні предмети проаналізовано зміст міжнародних та зарубіжних стандартів бухгалтерського обліку (IPSAS 17 [14]; FRS 30 [9]; Standard 17 [21]; GRAP 103 [9]; SFFAS 29 [20] та ін.), праці закордонних науковців (4-7; 11; 12; 15-19 та ін.) та інші джерела. У результаті аналізу вказаних джерел інформацію, яка уявляється доречною для користувачів, поділено на 5 груп: 1. Наявність музейних предметів; 2. Рух музейних предметів; 3. Фізичний стан музейних предметів; 4. Визнання та оцінка музейних предметів; 5. Політика управління музейними предметами. Встановлено, що така інформація:

- дозволить зробити узагальнені висновки про масштаби діяльності, значення, цінність колекцій музею та їх збереженість для сучасних і майбутніх поколінь;

- забезпечить користувачів даними про політику формування музейних фондів, способи придбання музейних предметів (купівля, безоплатна передача тощо) та причини їх вибуття (вилучення, безоплатна передача тощо);

- сприятиме розумінню користувачами особливостей відображення в балансі музейних предметів за вартістю;

- надасть можливість користувачам зрозуміти стратегію управління музейними предметами, а також обмеження на операції з ними;

- дозволить оцінити стан фінансування та ефективність використання бюджетних коштів, а саме: джерела фінансування на комплектування, збереження, вивчення, використання музейних фондів; планові та фактичні витрати на зберігання, реставрацію, обслуговування, експонування тощо музейних предметів тощо.

Для досягнення збалансованості якісних характеристик, доречність інформації необхідно розглядати і на відповідність цієї інформації іншим якісним характеристикам та обмеженням. Зокрема, не завжди інформація, яка уявляється доречною для користувачів, може бути достовірно представлена у звітності. Достовірність інформації переду- 
сім характеризується іï повнотою, нейтральністю (неупередженістю) та відсутністю суттєвих помилок [22]. Найбільш проблематичним у цьому контексті є відображення за вартістю музейних предметів. Адже в усіх без винятку українських музеях бухгалтерський облік музейних предметів за вартістю не ведеться, а у фондовому обліку їхня вартість відображена частково. Оцінити ж у короткий термін музейні предмети для цілей бухгалтерського обліку неможливо 3 багатьох причин. По-перше, питання обов'язковості оцінки музейних предметів не врегульовані на законодавчому рівні. Подруге, це доволі трудомісткий процес, який потребує затрат часу та праці компетентних оцінювачів. По-третє, вартість оцінювання при залученні експертів досить висока. Тобто в цій ситуації необхідно врахувати обмеження на інформацію, що стосується співвідношення вигід і витрат, оскільки вигоди від надання інформації про вартість усіх музейних предметів не виправдають витрати на формування цієї інформації. У такому випадку Концептуальні основи рекомендують розглянути питання про ослаблення однієї або декількох якісних характеристик для зниження витрат [22]. Таким чином, цілком логічно прагнути не до достовірного відображення вартості всіх музейних предметів, а до достовірного представлення інформації, яка дозволить користувачам зрозуміти особливості визнання та оцінки таких предметів та мінімізувати ступінь невизначеності фінансової та нефінансової інформації. У цьому контексті важливо встановити особливі підходи до визнання музейних предметів. Найбільш доцільним уявляється визнання лише нових придбань, без визнання музейних предметів, отриманих у попередні періоди (до моменту можливості їх повного визнання).

Обрану інформацію відповідно до Концептуальних основ необхідно розмежувати на: інформацію для відображення та інформаџію для розкриття. Варто зазначити, що як інформація для відображення, так і інформація для розкриття необхідні для досягнення мети фінансової звітності, проте інформація для відображення є основною, а інформація до розкриття - підвищує корисність основної інформації та сприяє розумінню користувачами порядку іiі формування [22].

Розмежування інформації за вказаними групами досить важливе для вирішення питань по іiі розміщенню (другий етап представлення інформащії), оскільки дозволяє сформувати масиви корисної інформації, які будуть відображені в основних формах звітності або розкриті в примітках до неї. При цьому ключовим для розміщення інформації в звітності є відповідність об'єкта критеріям визнання або ж передбачені нормативно-правовими актами особливості такого визнання. Також важливо враховувати, що надмірна кількість інформації може ускладнити розуміння користувачами показників звітності. Загальні характеристики інформації для відображення та розкриття, а також та підходи до її розміщення наведені в табл. 1.

Таблиця 1

Характеристика та розміщення інформащії для відображення та розкриття

\begin{tabular}{|c|c|c|c|}
\hline $\begin{array}{c}\text { Найменування } \\
\text { інформації }\end{array}$ & $\begin{array}{c}\text { Загальне призначення } \\
\text { інформації } \\
\end{array}$ & Зміст інформації & $\begin{array}{l}\text { Розміщення } \\
\text { інформації }\end{array}$ \\
\hline $\begin{array}{c}\text { Інформація для } \\
\text { відображення }\end{array}$ & $\begin{array}{l}\text { Основна інформація фі- } \\
\text { нансової звітності. }\end{array}$ & $\begin{array}{l}\text { Інформація про фінансовий стан, фінан- } \\
\text { сові результати діяльності і рух грошо- } \\
\text { вих коштів }\end{array}$ & $\begin{array}{l}\text { Відображається } \\
\text { в основних фор- } \\
\text { мах звітності }\end{array}$ \\
\hline $\begin{array}{l}\text { Інформація для } \\
\text { розкриття }\end{array}$ & $\begin{array}{l}\text { Підвищує корисність } \\
\text { інформації для відобра- } \\
\text { ження. Необхідна для } \\
\text { розуміння користувача- } \\
\text { ми фінансової звітності }\end{array}$ & $\begin{array}{l}\text { Інформація про застосовування обліко- } \\
\text { вих політик, деталізація інформації для } \\
\text { відображення, дані про об’єкти, які не } \\
\text { відповідають інформації для відобра- } \\
\text { ження (наприклад, коли об’єкт відпові- } \\
\text { дає визначенню елемента, але не відпові- } \\
\text { дає іншим критеріям визнання) тощо }\end{array}$ & $\begin{array}{l}\text { Відображається } \\
\text { в примітках до } \\
\text { фінансової звіт- } \\
\text { ності, пояснен- } \\
\text { нях тощо }\end{array}$ \\
\hline
\end{tabular}

Джерело: сформовано автором за даними [22]. 
ФІНАНСОВІ РЕСУРСИ: ПРОБЛЕМИ ФОРМУВАННЯ ТА ВИКОРИСТАННЯ

При запропонованому підході до визнання музейних предметів у балансі необхідно відображати за вартістю лише нові надходження музейних предметів. Усю іншу інформацію стосовно музейних предметів слід визначати як інформацію для розкриття та відображати в примітках до фінансової звітності.

Концептуальними основами визначено, що рішення про розміщення інформації стосуються не тільки звіту, в якому її необхідно розміщувати, а і частини звіту [22]. 3 огляду на це, визнані активи спадщини повинні бути відображені в першому розділі затвердженої ф. № 1-дс «Баланс», який називається «Нефінансові активи». Таке твердження зумовлене належністю активів спадщини саме до ресурсів нефінансового характеру. Для розкриття інформації в чинній ф. № 5-дс «Примітки до річної фінансової звітності» пропонується ввести додатковий розділ «Активи спадщини». Проте, примітки до фінансової звітності не повинні обмежуватись затвердженою формою, адже не вся інформація про музейні предмети, що пропонується до розкриття, може бути відображена в таблицях до ф. № 5-дс. Таке твердження відповідає нормам міжнародних стандартів, які не формалізують примітки, а також не суперечить визначенню приміток до річної фінансової звітності в НП(С)БОДС як сукупності «показників і пояснень, яка забезпечує деталізацію і обгрунтованість статей фінансових звітів, а також іншої інформації, розкриття якої передбачено відповідними національними положеннями (стандартами) бухгалтерського обліку в державному секторі» [1]. Крім того, НП(С)БОДС 101 «Подання фінансової звітності» встановлюе розкриття в примітках до фінансової звітності інформації:

- яка не наведена безпосередньо у фінансовій звітності, але є обов'язковою згідно 3 відповідними НП(С)БОДС;

- що містить додатковий аналіз статей звітності, потрібний для забезпечення її зрозумілості та доречності [1].

3 огляду на вказане, в запропонованому до чинної ф. № 5-дс «Примітки до річної фінансової звітності» розділі «Активи спадщини» в розрізі груп активів спадщини доцільно розкривати інформацію про: залишок активів спадщини на початок року в кількісному й вартісному виразі; переоцінку, вибуття, надходження чи інші зміни протягом року в кількісному й вартісному виразі; амортизацію, якщо така нараховується; залишок на кінець року в кількісному й вартісному виразі; причини вибуття активів спадщини, їхня вартість та кількість; збільшення вартості та кількості активів спадщини 3 вказівкою причин такого збільшення; кількість і вартість активів спадщини, які потребують поліпшення (реконструкції, реставрації тощо); законодавчі обмеження стосовно активів спадщини.

Пояснення до фінансової звітності в частині музейних предметів повинні розкривати:

- значення активів спадщини (музейних предметів) для суб'єкта державного сектору;

- опис основних типів музейних предметів;

- особливості визнання музейних предметів, суб'єктів та спосіб оцінки (переоцінки) музейних предметів, витрати на оцінку (переоцінку);

- політику управління музейними предметами, зокрема: стратегію управління музейними предметами; особливості використання музейних предметів та обмеження на операції з ними; джерела фінансування процесів комплектування, збереження, вивчення, використання музейних фондів; планові та фактичні витрати на зберігання, реставрацію, обслуговування, експонування тощо музейних предметів;.

- іншу інформацію, яка здатна підвищити якісні характеристики фінансової звітності.

Tретій етап представлення стосується організації інформації, призначеної для відображення чи розкриття. На цьому етапі вирішуються питання групування та упорядкування інформації у фінансовій звітності, зокрема стосовно елементів звітності [22]. 
Це досить важливе питання, адже в чинній формі балансу для відображення активів спадщини окремої статті не передбачено, а інформацію про так звані «музейні фонди» необхідно включати до статті «Основні засоби». На наш погляд, при визнанні активів спадщини їх включення до складу основних засобів призведе до викривленого розуміння звітної інформації користувачами.

У цьому контексті досить важливим є судження загального характеру стосовно суттєвості та об'єднання, яке передбачене міжнародними стандартами. У національних стандартах поняття «суттєвість та об’єднання» відсутнє, ймовірно тому, що форми фінансової звітності затверджуються на державному рівні. Проте вказаного судження необхідно дотримуватись 3 метою удосконалення звітної інформації. Так, відповідно до МСБОДС 1 «Подання фінансових звітів»: по-перше, статті, які є суттєвими та відрізняються за характером і призначенням, слід подавати у фінансовій звітності окремо; по-друге, статті, які $\epsilon$ суттєвими за величиною, але мають подібний характер, можна об'єднувати; по-третє, стаття, яка не достатньо суттєва для обгрунтування ії̈ окремого подання у фінансових звітах, може бути достатньо суттєвою для її окремого подання в примітках [13].

Враховуючи, що музейні предмети разом з іншими активами спадщини мають досить специфічні ознаки, які вирізняють їх від інших активів, при визнанні їх слід відображати окремою статтею балансу в розділі «Нефінансові активи» 3 подальшим їі розшифруванням у примітках чи поясненнях до фінансової звітності. Обгрунтування наведених пропозицій на відповідність судженню про суттєвість та об'єднання міститься в табл. 2.

Таблиця 2

Врахування судження про суттєвість та об'єднання при формуванні пропозицій стосовно організаиії інформащзї про музейні предмети у фінансовій звітності

\begin{tabular}{|c|c|}
\hline Твердження & Обгрунтування \\
\hline $\begin{array}{l}\text { За умови визнання музейні предмети } \\
\text { повинні відображатись у балансі в } \\
\text { складі активів спадщини }\end{array}$ & $\begin{array}{l}\text { Такий підхід забезпечить відображення в одній статті активів зі } \\
\text { спільними ознаками, які вирізняють активи спадщини від інших } \\
\text { активів. }\end{array}$ \\
\hline $\begin{array}{l}\text { Активи спадщини повинні відобра- } \\
\text { жатись у балансі окремою статтею }\end{array}$ & $\begin{array}{l}\text { Об’єднання активів спадщини з іншими активами (наприклад, } \\
\text { основними засобами) з метою відображення їх однією статтею в } \\
\text { балансі не можливе, оскільки активи спадщини мають свої особ- } \\
\text { ливі ознаки та призначення. Крім того, активи спадщини можуть } \\
\text { бути матеріальні і нематеріальні, що також унеможливлює їх } \\
\text { віднесення до інших статей }\end{array}$ \\
\hline $\begin{array}{l}\text { Окремо розкривати інформацію про } \\
\text { всю сукупність музейних предметів } \\
\text { та особливості управління ними в } \\
\text { примітках до фінансової звітності }\end{array}$ & $\begin{array}{l}\text { Розкриття в примітках до фінансової звітності інформації про } \\
\text { активи спадщини в розрізі їх видів забезпечить розуміння їх зна- } \\
\text { чення, кількості, фізичного стану, особливостей оцінки, понесе- } \\
\text { них витрат на реставрацію, зберігання тощо. }\end{array}$ \\
\hline
\end{tabular}

Джерело: розроблено автором за даними [13].

Не менш важливим завданням $є$ і організація інформації в примітках до фінансової звітності. Відповідно до Концептуальних основ, інформацію до розкриття в примітках слід організовувати так, щоб іiі відношення до елементів, відображених в основних формах фінансової звітності, було зрозумілим [22].

Запропоновані підходи до організації інформації про музейні предмети в балансі та примітках до фінансової звітності сприятимуть дотриманню таких якісних характеристик корисності інформації як зрозумілість, порівнянність, верифікація (можливість перевірки).

Висновки і пропозиції. Отже, вирішення завдань по вибору, розміщенню та організації звітної інформації стосовно музейних предметів спрямоване на надання користувачам фінансової звітності корисної інформації про наявність, рух та стан музейних предметів; їх визнання та оцінку; політику управління. Розміщення цієї інформації у звітності передбачає ії поділ на інформацію для відображення та інформацію для розк- 
ФІНАНСОВІ РЕСУРСИ: ПРОБЛЕМИ ФОРМУВАННЯ ТА ВИКОРИСТАННЯ

риття, що передусім залежить від особливостей визнання музейних предметів. Авторський підхід до визнання музейних предметів передбачає визнання лише нових надходжень без визнання музейних предметів, отриманих в попередні періоди (до моменту можливості їх повного визнання).

Запропоновано удосконалення ф. № 1-дс «Баланс» через введення до розділу «Нефінансові активи» статті «Активи спадщини» для відображення музейних предметів та інших активів спадщини, які визнаються, та ф. № 5-дс «Примітки до річної фінансової звітності» через включення додаткового розділу «Активи спадщини» для розкриття інформації в розрізі груп активів спадщини про: залишок активів спадщини на початок та кінець року, їх переоцінку, вибуття, надходження чи інші зміни протягом року в (кількісному і вартісному виразі); амортизацію, якщо така нараховується; кількість та вартість активів спадщини, які потребують поліпшення (реконструкції, реставрації тощо); законодавчі обмеження стосовно активів спадщини. Додатково в поясненнях до фінансової звітності запропоновано розкривати дані про: значення активів спадщини (музейних предметів) для суб'єкта державного сектору; основні типи музейних предметів; особливості визнання музейних предметів, суб'єктів та спосіб їх оцінки (переоцінки), витрати на оцінку (переоцінку); короткий опис політики управління музейними предметами.

Надані пропозиції дозволять користувачам зробити висновки про наявність, рух, стан музейних предметів та політику управління ними, що підвищить якісні характеристики фінансової звітності суб'єкта державного сектору.

\section{Список використаних джерел}

1. Національне положення (стандарт) бухгалтерського обліку в державному секторі 101 «Подання фінансової звітності»: затв. наказом МФУ від 28.12.2009 р. № 1541. URL: https://zakon.rada.gov.ua/laws/show/z0103-10.

2. Гливенко В. В., Лень В. С. Суттєвість у бухгалтерському обліку суб'єктів державного сектору. Проблеми і перспективи економіки та управління. 2018. № 3(15). С. 171-183.

3. Accrual Practices and Reform Experiences in OECD Countries. OECD Publishing, Paris. OECD/IFAC. 2017. URL: https://www.iaasb.org/system/files/publications/files/Accrual-Practicesand-Reform-Experiences-OECD-Countries.pdf.

4. Aversano N., Christiaens J. Governmental financial reporting of heritage assets from a user needs perspective: Governmental Financial Reporting of Heritage Assets. Financial Accountability \& Management. 2014. № 30(2). P. 150-174. URL: https://dx.doi. org/10.1111/faam.12032.

5. Barker P. Heritage Assets Can Accounting do Better? Accountancy Ireland. 2006. № 38(4). P. $48-50$.

6. Barton A. D. Accounting for public heritage facilities - assets or liabilities of the government? Accounting, Auditing \& Accountability Journal. 2000. № 13(2). P. 219-236. URL: https://dx.doi.org/ 10.1108/09513570010323434.

7. Biondi L., Giulio Grandis F., Mattei G. Financial reporting for heritage assets. Towards an international public sector accounting standard? Working Paper. 2018. № 1. 20 p. URL: https://docplayer.net/153094140-Financial-reporting-for-heritage-assets-towards-an-internationalpublic-sector-accounting-standard.html.

8. Financial Reporting for Heritage in the Public Sector. Consultation Paper. IPSASB. 2017. URL: $\quad$ https://www.ifac.org/system/files/publications/files/IPSASB-Consultation-Paper-FinancialReporting-for-Heritage-in-the-Public-Sector.pdf.

9. FRS 30 «Heritage assets»: Accounting Standards Board UK, June 2009. URL: http://frc.org.uk/Our-Work/Publications /ASB/FRS-30-Heritage-Assets-(June-2009)-File.pdf.

10. GRAP 103 «Heritage Assets»: ASB, South Africa, July 2008. URL: http://www.asb.co.za/LinkClick.aspx? fileticket=ownCoJYOxxc\%3d\&portalid $=0$.

11. Hay L. E., Antonio J. F. What users want in government financial reports. Journal of Accountancy. 1990. № 170(2). P. 91. 
ФІНАНСОВІ РЕСУРСИ: ПРОБЛЕМИ ФОРМУВАННЯ ТА ВИКОРИСТАННЯ

12. Hone P. The financial value of cultural, heritage and scientific collections: a publicmanagement necessity. Australian Accounting Review. 1997. Vol. 7. № 1. P. 38-43.

13. IPSAS 1 «Presentation of Financial Statements»: IPSASB, May 2000 (revised 2006). URL: https://www.ifac.org/system/files/publications/files/IPSASB-HandBook-2018-Volume-1.pdf.

14. IPSAS 17 «Property, plant and equipment»: IPSASB, December 2001 (revised 2006). URL: https://www.ifac.org/system/files/publications /files/ipsas-17-property-plant-2.pdf.

15. Lacerra A., Stafford A. Heritage assets: The UK accounting challenge. In Proceedings from CIGAR 12th biennial conference. 2009. Modena: Italy.

16. Lee J., Fisher G. Infrastructure assets disclosure in Australian public sector annual reports. Accounting Forum. 2004. № 28(4). P. 349-368. URL:https://dx.doi.org/10.1016/j.accfor.2004.08.002.

17. Mack J., Ryan C. Reflections on the theoretical underpinnings of the general-purpose financial reports of Australian government departments. Accounting, Auditing \& Accountability Journal. 2006. № 19(4). P. 592-612. URL: https://dx.doi.org/10.1108/09513570610679146.

18. Noaman, N., Ouda, H., Christiaens, J. Indexing financial reporting information for heritage Management. E a M: Ekonomie a Management. 2018. № 21(2). P. 186-207. URL: https://www.researchgate.net/publication/326035405_Indexing_financial_reporting_information for_heritage_management.

19. Robbins W. A. Consensus between preparers and users of municipal annual reports: an empirical analysis. Accounting and Business Research. 1984. № 14(54). P. 157-162. URL: https://www.tandfonline.com/doi/10.1080/00014788.1984.9729202.

20. SFFAS 29 «Heritage Assets and Stewardship Land»: FASAB, July 7, 2005. URL: http://files.fasab.gov/pdffiles/handbook_sffas_29.pdf.

21. Standard 17 «Heritage Asset»: CNOCP, February 2013. URL: http://www.economie.gouv.fr/ files/files/directions_services/cnocp-en/opinion/board_opinion/2013/Opinion-n-2013-03-Standard-17.pdf.

22. The Conceptual Framework for General Purpose Financial Reporting by Public Sector Entities: IPSASB, January 2013. URL: https://www.ifac.org/system/files/publications/files/IPSASBPublic-Sector-Conceptual-Framework.pdf.

\section{References}

1. Natsionalne polozhennia (standart) bukhhalterskoho obliku v derzhavnomu sektori 101 «Podannia finansovoi zvitnosti» [National Public Sector Accounting Standard (Standard) 101 "Presentation of Financial Statements"]. № 1541 (28.12.2009). Retrieved from https://zakon.rada.gov.ua/laws/show/z0103-10.

2. Hlyvenko, V. V., Len, V. S. (2018). Cuttievist u bukhhalterskomu obliku subiektiv derzhavnoho sektoru [Significance in accounting subjects of the state sector]. Problemy i perspektyvy ekonomiky ta upravlinnia - Problems and prospects of economics and management, 3(15), 171-183 [in Ukrainian].

3. Accrual Practices and Reform Experiences in OECD Countries (2017). OECD Publishing, Paris. OECD/IFAC. Retrieved from https://www.iaasb.org/system/files/publications/files/AccrualPractices-and-Reform-Experiences-OECD-Countries.pdf.

4. Aversano, N., Christiaens, J. (2014). Governmental financial reporting of heritage assets from a user needs perspective: Governmental Financial Reporting of Heritage Assets. Financial Accountability \& Management, 30(2), 150-174. Retrieved from https://dx.doi.org/10.1111/faam.12032.

5. Barker, P. (2006). Heritage Assets Can Accounting do Better? Accountancy Ireland, 38(4), 48-50.

6. Barton, A. D. (2000). Accounting for public heritage facilities - assets or liabilities of the government? Accounting, Auditing \& Accountability Journal, 13(2), 219-236. Retrieved from https://dx.doi.org/10.1108/09513570010323434.

7. Biondi, L., Giulio Grandis, F., Mattei, G. (2018). Financial reporting for heritage assets. Towards an international public sector accounting standard? Working Paper, 1, 20. Retrieved from https://docplayer.net/153094140-Financial-reporting-for-heritage-assets-towards-an-internationalpublic-sector-accounting-standard.html.

8. Financial Reporting for Heritage in the Public Sector (2017). Consultation Paper. IPSASB. Retrieved from https://www.ifac.org/system/files/publications/files/IPSASB-Consultation-PaperFinancial-Reporting-for-Heritage-in-the-Public-Sector.pdf. 
ФІНАНСОВІ РЕСУРСИ: ПРОБЛЕМИ ФОРМУВАННЯ ТА ВИКОРИСТАННЯ

9. FRS 30 «Heritage assets»: Accounting Standards Board UK (June 2009). Retrieved from http://frc.org.uk/Our-Work/Publications /ASB/FRS-30-Heritage-Assets-(June-2009)-File.pdf.

10. GRAP 103 «Heritage Assets»: ASB, South Africa (July 2008). Retrieved from http://www.asb.co.za/LinkClick.aspx? fileticket=ownCoJYOxxc\%3d\&portalid=0.

11. Hay, L. E., Antonio, J. F. (1990). What users want in government financial reports. Journal of Accountancy, 170(2), 91.

12. Hone, P. (1997). The financial value of cultural, heritage and scientific collections: a publicmanagement necessity. Australian Accounting Review, 7 (1), 38-43.

13. IPSAS 1 «Presentation of Financial Statements»: IPSASB (May 2000 (revised 2006)). Retrieved from https://www.ifac.org/system/files/publications/files/IPSASB-HandBook-2018-Volume-1.pdf.

14. IPSAS 17 «Property, plant and equipment»: IPSASB (December 2001 (revised 2006)). Retrieved from https://www.ifac.org/system/files/publications /files/ipsas-17-property-plant-2.pdf.

15. Lacerra, A., Stafford, A. (2009). Heritage assets: The UK accounting challenge. In Proceedings from CIGAR 12th biennial conference. Modena: Italy.

16. Lee, J., Fisher, G. (2004). Infrastructure assets disclosure in Australian public sector annual reports. Accounting Forum, 28(4), 349-368. Retrieved from https://dx.doi.org/10.1016/ j.accfor.2004.08.002.

17. Mack, J., Ryan, C. (2006). Reflections on the theoretical underpinnings of the general-purpose financial reports of Australian government departments. Accounting, Auditing \& Accountability Journal, 19(4), 592-612. Retrieved from https://dx.doi.org/10.1108/09513570610679146.

18. Noaman, N., Ouda, H., Christiaens, J. (2018). Indexing financial reporting information for heritage Management. E a M: Ekonomie a Management, 21(2), 186-207. Retrieved from https://www.researchgate.net/publication/326035405_Indexing_financial_reporting_information_for_ heritage_management.

19. Robbins, W. A. (1984). Consensus between preparers and users of municipal annual reports: an empirical analysis. Accounting and Business Research, 14(54), 157-162. Retrieved from https://www.tandfonline.com/doi/10.1080/00014788.1984.9729202.

20. SFFAS 29 «Heritage Assets and Stewardship Land»: FASAB (July 7, 2005). Retrieved from http://files.fasab.gov/pdffiles/handbook_sffas_29.pdf.

21. Standard 17 «Heritage Asset»: CNOCP (February 2013). Retrieved from http://www.economie.gouv.fr/files/files/directions_services/cnocpen/opinion/board_opinion/2013/Opinion-n-2013-03-Standard-17.pdf.

22. The Conceptual Framework for General Purpose Financial Reporting by Public Sector Entities: IPSASB (January 2013). Retrieved from https://www.ifac.org/system/ files/publications/files/IPSASB-Public-Sector-Conceptual-Framework.pdf.

|Герасименко Ольга Миколаївна - старший викладач кафедри бухгалтерського обліку, Університет державної фіскальної служби України (вул. Університетська, 31, м. Ірпінь, 08201, Україна)

Герасименко Ольга Николаевна - старший преподаватель кафедры бухгалтерского учета, Университет государственной фискальной службы Украины (ул. Университетская, 31, г. Ирпень, 08201, Украина)

Herasymenko Olha - senior lecturer of the department of Accounting, University of State Fiscal Service of Ukraine

(31 Universytetska Str., 08201 Irpin, Ukraine)

E-mail: cina@ukr.net

ORCID: http://orcid.org/0000-0002-4511-4306

Герасименко О. Надання корисної інформації про музейні предмети у фінансовій звітності суб'єкта державного сектору. Проблеми і перспективи економіки та управління. 2019. № 4 (20). С. 442-450. 